\title{
Effect of Some Mineral Oils Alone and Their Mixtures with Cyhalothrin on The In Vitro Activity of Adenosine Triphosphatase Enzyme (ATPase) Extracted from Spodoptera Littoralis Larvae Brain
}

\author{
Ismail, Seham M. ${ }^{1}$, Nader Shaker ${ }^{2}$
}

\begin{abstract}
The toxicity effects of three Mineral oils (Folic; Kemesol and National oil) alone and pretreated with Cyhalothrin (Pyrethroid) insecticide on the fourth larval instars of laboratory and field strains of Spodoptera littoralis have been evaluated. The results showed that Folic oil was the most potent against both two strains followed by Kemesol and National oil showed to have less toxic effect. The effect of $L_{50}$ of the tested oils and the interaction of Mineral oils with Cyhalothrin on the in vivo inhibition of ATPase from Spodoptera littoralis brain was investigated. Results proved that pretreated of Folic oil with Cyhalothrin incressed the percentage inhibition which found that to be 95.8 and $\mathbf{9 0 . 7 \%}$ for lab and field strains respectively, while the percentage inhibition found by pretreated the Kemesol oil with Cyhalothrin were 90.5 and 88.6\% for lab and field strains Spodoptera respectively, in the other hand the percentage inhibition found by pretreated the National oil with Cyhalothrin were 76.2 and $\mathbf{7 1 . 3 \%}$ for lab and field strains Spodoptera respectively. The results emphasized that $I_{50}$ and $K_{i}$ values decreased when Folic and Kemesol oil pretreated with Cyhalothrin, so there were significant differences among the chemical combinations, which caused more reduction effect than signal treatment, and they affected enzyme activity by the same trend so results proved that ATPase was sensitive to the Folic and Kemesol oil. The present study open gate that physical toxicant can play important role to increase pesticide toxicity. Generally, Mineral oils pretreated with Cyhalothrin produce a new trend will lead to reduce the field dose of the Pyrethroid insecticides, enhance the role of beneficial insects and reduce the cost of pest control.
\end{abstract}

\section{INTRODUCTION}

The cotton leafworm, Spodoptera littoralis is considered a very important pest in Egypt, which cause serios damage and losses in field crops. Several studies were carried out on chemical control (pesticide) of this insect and development of resistance was illustrated by Keddis et al., (1988); Ishaaya and Klein (1990); Martin et al., (2000) \& El-Aw et al., (2002). In the other target to the extensive on target organisms uses of chemical toxicants for pest caused many problems, such as acute and chronic human and animal toxicity, development of insect resistance to chemicals and environmental pollution. So we need alternative effective and environmentally safe insecticides such as mineral oils
(MARL, 1997). Local sprays of mineral oils are used for years against scale insects, mealybugs, thrips, aphids and mites on different crops and fruit trees, (Moursi, 1996 \& El-Deeb et al., 2002). Oil sprays are used most commonly in horticulture to control scale insects and mites (Chapman et al., 1952: Micks and Berlin 1970 \& El-Sebae et al., 1976) stated that resistance was not recorded for mineral oils which still have the advantage of being effective to resistant strains.

Therefore, the present work in an attempt to implement a new promising approach to suppress populations of this insect by using three Mineral oils (Folic; Kemesol and National oil) to evaluate alone and their pretreated Cyhalothrin (Pyrethroid) on Spodoptera larvae to decrease the environmental pollution and decrease development of resistance, due to the continous of chemical application of pesticides in the field. The study was directed to throw the effect of these chemicals on the activity of ATPase.

\section{MATERIALS AND METHODS}

Insect:

Laboratory strain of cotton leafworm, Spodoptera littoralis was chosen for bioassays and biochemical assessments. This strain start as field strain reared under laboratory conditions for several years in central lab. of pesticides, Agricultural Research Centre (ARC) Cairo, Egypt. Field strain of Spodoptera littoralis egg masses were collected from cotton fields at Abeis area in Alexandria Governorate, eggs masses let to be hatching in laboratory conditions of $27 \pm 2^{\circ} \mathrm{C}$ and $65-70 \% \mathrm{RH}$. The $4^{\text {th }}$ larval instar used in study.

Chemical:

Cyhalothrin (Pyrethroid) provided as technical grade insecticides from U.S.A. Environmental Protection Agency (EPA), USA. Mineral oils were used in this study namely: Folic oil $82 \%$ E.C was obtained from Kafer El-Ziat Pesticides and Chemicals Co. Kemesol oil 95\% E.C and National oil 95\% E.C were obtained from KEMEX Co. as commercial product from pesticide stores.

Bioassay tested:

Castor leaves disc $\left(2 \mathrm{~cm}^{2}\right)$ were dipped for $1 \mathrm{~min}$ in each concentration of the tested Mineral oils. Control

\footnotetext{
${ }^{1}$ Central Laboratory of Pesticides, Sabahia, Alexandria, A.R.C.

2 Pesticide Chemistry Dept., Fac. of Agrie, Alex., Univ.

Received December24, 2008, Accepted December 30, 2008
} 
plants were dipped in distilled water. Treated and control plants were air-dried for 3 hrs. Three replicates for each all treatments and control with ten larvae in each replicate. Number of alive and dead larvae per replicate was counted 24 and 48hr, after treatment. Concentration-mortality percentages were calculated and corrected for natural mortality according to Abbott equation (Abbott, 1925). LC $_{50}$ values were calculated by using the probit-analysis method of Finney (1971).

Enzyme preparation and activity assay:

Head capsoul from $S$. littoralis fourth-instar larvae was dissected and homogenized in a solution of $0.32 \mathrm{M}$ sucrose, $1 \mathrm{mM}$ EDTA and $4 \mathrm{mM}$ tris- $\mathrm{HCl}$ buffer $(\mathrm{pH}$ 7.4). The homogenate was filtered through two layers of cheese cloth. Mitochondrial ATPase was prepared according to the method reported by Koch (1969), by differential centrifugation of the homogenate at $8000 \mathrm{Xg}$ for $10 \mathrm{~min}$. The supernatant was then centrifuged at $20000 \mathrm{Xg}$ for $30 \mathrm{~min}$. The formed pellets were then suspended in the buffer and stored at $\left(-4^{\circ} \mathrm{C}\right)$ for use.

The ATPase activity measurements performed according to the method reported by Koch (1969), with slight modification by Morshedy (1980) using tris-HCl buffer instead of imidiazol buffer. Absorbancy of inorganic phosphate (Pi) was measured at $750 \mathrm{~nm}$ (Taussky and Shorr, 1953). The method was based on the spectrophotometric determination of the inorganic phosphate $(\mathrm{Pi})$ liberated from the hydrolysis reaction of the ATP, mediated by the enzyme. The ATPase activity was measured in a total volume of $1 \mathrm{ml}$. The homogenate preparation was mixed with a reaction mixture $(700 \mu \mathrm{l})$ containing $100 \mathrm{mM} \mathrm{Na}^{+}, 20 \mathrm{mM} \mathrm{K}^{+}, 5 \mathrm{mM} \mathrm{Mg}^{2+}$ chloride, $40 \mathrm{mM}$ tris- $\mathrm{HCl}$ buffer (pH 7.4), and 5mM ATP. The volume was completed to $850 \mu l$ with the buffer. The mixture was incubated for $15 \mathrm{~min}$, in a shaking water bath at $37^{\circ} \mathrm{C}$. The reaction was stopped by adding $150 \mu \mathrm{l}$ trichloroacetic acid (TCA, 30\%). Hydrolyzed Pi was determined according to the method, described by Taussky and Shorr, (1953).

Protein content in prepared homogenates of $S$. littoralis fourth-instar larvae was assayed spectrophotometrically by the method of Lowery et al., (1951) at 750nm using bovine serum albumin (BSA) as a standard protein.

Inhibition of ATPase activity:

The inhibition of ATPase was determined in head capsoul fourth-instar larvae of $S$. littoralis using the $\mathrm{LC}_{50}$ value of each of the tested Mineral oils. To check whether these tested oils could enhance the inhibitory effect of the inhibitor insecticide (Cyhalothrin), the oil which produce the inhibition of the enzymatic activity was mixed with Cyhalothrin. The method of Dixon and Webb (1964) was adopted to draw the Dixon-plots by plotting $1 / \mathrm{V}$ versus concentrations of the inhibitor at two concentrations of the substrate. ATP (the substrate of ATPase)concentrations were 3.0 and $5.0 \mathrm{mM}$. Estimation of $\mathrm{I}_{50}$ value was carried out by pre incubating the enzyme with the different concentrations of inhibitor for 30min.

\section{RESULTS AND DISCUSSION}

\section{Toxicity of some Mineral oils:}

The results of the toxicity of the Mineral oils expressed in terms of $\mathrm{LC}_{50}$ are given in Table (1) for $4^{\text {th }}$ instar larvae of $S$. littoralis. $\mathrm{LC}_{50}$ values after $24 \mathrm{hr}$ were 8.2; 12 and 15.1ppm for Folic; Kemesol and National oil respectively, against Spodoptera lab strain. For field strain $\mathrm{LC}_{50}$ values were $10.3 ; 14.4$ and $17.1 \mathrm{ppm}$ for these three oils respectively. While $\mathrm{LC}_{50}$ values, after $48 \mathrm{hr}$ were $3.2 ; 4.8$ and $7.9 \mathrm{ppm}$ for these three oils respectively, against lab strain. For field strain $\mathrm{LC}_{50}$ values were $5.2 ; 7.6$ and $9.8 \mathrm{ppm}$ for these three oils respectively. The $\mathrm{LC}_{50}$ values after $72 \mathrm{hr}$ for lab strain were $1.6 ; 3.3$ and $4.2 \mathrm{ppm}$ for these three oils respectively, against Spodoptera, while the $\mathrm{LC}_{50}$ values for field strain were 3.3; 5.1 and $7.4 \mathrm{ppm}$ for these three oils respectively. Folic oil was the most potent against both lab and field strains, followed by Kemesol oil while National oil was the least active, against $S$. littoralis. The tested oils exhibited more toxic effect on lab strain than field strains. These results are in agreement with many investigators. El-Attal et al., (1983) \& Moustafa and ElAttal (1985) reported that Mineral oil more toxic against cotton leafworm. El-Halawany et al., (1987) who reported Mineral oil used successfully on citrus trees against both of tested insects. Amer et al., (2001) found that $\mathrm{Kz}$ oil more toxic against Tetranychus urticae. Also Hazzard et al., (2003) reported the Mineral oil alone provided better control of Spodoptera fumgiperda (Lepidoptera: Noctuidae) compared with corn oil and $B$. thuringiensis. Mohmoud et al., (2006) reported the Mineral oils were the most efficient compound for controlling Russellaspis pustulans on apple trees.

Table 1. $\mathrm{LC}_{50}$ values of some Mineral oils to $4^{\text {th }}$ instar $S$. littoralis Larvae

\begin{tabular}{ccccccc}
\hline \multirow{2}{*}{ Time (hr) } & \multicolumn{6}{c}{ LC $_{\mathbf{5 0}}(\mathbf{p p m})$} \\
\cline { 2 - 7 } & \multicolumn{2}{c}{ Folic oil } & \multicolumn{2}{c}{ Kemesol oil } & \multicolumn{2}{c}{ National oil } \\
\cline { 2 - 7 } & Lab strain & Field strain & Lab strain & Field strain & Lab strain & Field strain \\
\hline 24 & 8.2 & 10.3 & 12 & 14.4 & 15.1 & 17.1 \\
48 & 3.2 & 5.2 & 4.8 & 7.6 & 7.9 & 9.8 \\
72 & 1.6 & 3.3 & 3.3 & 5.1 & 4.2 & 7.4 \\
\hline
\end{tabular}


Toxicity of Cyhalothrin alone or pretreated with the $\mathbf{L C}_{\mathbf{5 0}}$ values of Mineral oils against $\boldsymbol{S}$. littoralis larvae:

The $\mathrm{LC}_{50}$ values of Cyhalothrin after $24 \mathrm{hr}$ were 0.013 and $0.019 \mathrm{ppm}$ against Spodoptera lab and field strains respectively, the $\mathrm{LC}_{50}$ values after $48 \mathrm{hr}$ were 0.011 and $0.016 \mathrm{ppm}$ respectively, against Spodoptera lab and feld strains respectively,Table (2). The interaction of oils with Cyhalothrin against lab and field strains of Spodoptera larvae were studied, larvae were allowed to fed on castor oil leave discs treated with $\mathrm{LC}_{50}$ of the different Mineral oils.

The $\mathrm{LC}_{50}$ values of Cyhalothrin pretreated with the $\mathrm{LC}_{50}$ values of Folic; Kemesol and National oil on lab and field strains of Spodoptera larvae are presented in Table (2). The $\mathrm{LC}_{50}$ value of Cyhalothrin when pretreated with oils was lower than $\mathrm{LC}_{50}$ of Cyhalothrin alone in lab or field Spodoptera strains. The enhancement of toxicity is calculated as a Potentiation factor (P.f.) (Table 2). P.f. values for Folic; Kemesol and National oil are 3.25; 2.16 and 1.08 respectively after $24 \mathrm{hr}$ treatment, for lab strain, while the P.f. values of three Mineral oils are $2.71 ; 2.11$ and 1.26 respectively after $24 \mathrm{hr}$ treatment, for field strain. In the other hand the P.f. values of three tested Mineral oils are $5.50 ; 3.66$ and 1.10 respectively after $48 \mathrm{hr}$ treatment, for lab strain. Also the P.f. values of three Mineral oils are $3.20 ; 2.28$ and 1.23 respectively after $48 \mathrm{hr}$ treatment, for field strain. This resultes are agreement with finding of Rodriguez et al., (1966) showed that Mineral oil plus insecticide under studied were effective against the coffee leaf-miner. Hopkins et al., (1982) reported that diflubenzuron combined with Mineral oil significantly reduced the number of the adult weevil Anthonomus grandis Boheman. Moustafa and El-Attal (1985) were found to increase the potency of insecticide against the cotton leafworm and thrips. Omar et al., (1987) showed that Mineral oils improved the efficiency of the insecticide used against both of tested insects. AboShanab (2005) who reported that IGRs increased activity when mixed with Mineral oils. Ismail et al., (2006) reported the Cypermethrin and Mineral oil
(Supermasrona) have a moderate toxicity against Tetranychus urticae.

These results observed of new trend will lead to reduce the field dose of the Pyrethroid insecticides, enhance the role of beneficial insects and reduce the cost of pest control. So the additive effect was obtained in three tested Mineral oils with Cyhalothrin, while the potentiation effect was observed in Folic; Kemesol and National oil. The addition of Mineral oil may be prolonged the residual activity of candidate. The facilitate foliar absorption of pesticides. The evaporation from a falling oil emulsion dropet is shower than from a water dropet, and this is useful in increasing foliar retention and reducing drift.

In vivo inhibition of brain $S$. littoralis ATPase activity:

The in vivo inhibitory of the $\mathrm{LC}_{50}$ values of three Mineral oils against to the Spodoptera $4^{\text {th }}$ instar lab and field strains larval ATPase are shown in the data given in Table (3). The data declared that Folic and Kemesol oil exhibited the highest percentages of reduction of ATPase activity as values were 67.5 and $58.6 \%$ respectively for lab strain, while values were 64.8 and $55.9 \%$ respectively, for field strain. On the other hand, National oil not active as ATPase inhibitor, as percentages of reduction on ATPase activity as values were 53.4 and $50.2 \%$ respectively, for lab strain and field strain.

Data in Table (3) summarize the interaction of Folic; Kemesol and National oil inhibitory effect of Cyhalothrin on activity of ATPase. The results proved that pretreated of Folic; Kemesol and National oil with Cyhalothrin induce increase the inhibition of enzyme activity. The inhibition of ATPase by Cyhalothrin alone were 75.7 and $70.1 \%$ for lab and field strains respectively. While the inhibition increased to be 95.8 and $90.7 \%$ for lab and field strains respectively, when Folic oil pretreated with Cyhalothrin. Morever the inhibition of enzyme activity increased to be 90.5 and $88.6 \%$ for lab and field strains respectively, when Kemesol oil pretreated with Cyhalothrin. Also the

Table 2. Comparative toxicities of Cyhalothrin alone or pretreated with some Mineral oils on Spodoptera larvae

\begin{tabular}{|c|c|c|c|c|c|c|c|c|}
\hline \multirow{4}{*}{ Compounds } & \multicolumn{8}{|c|}{$\mathrm{LC}_{\mathbf{5 0}}(\mathrm{ppm})$} \\
\hline & \multicolumn{4}{|c|}{$24 \mathrm{hr}$} & \multicolumn{4}{|c|}{$48 \mathrm{hr}$} \\
\hline & \multicolumn{2}{|c|}{ Lab strain } & \multicolumn{2}{|c|}{ Field strain } & \multicolumn{2}{|c|}{ Lab strain } & \multicolumn{2}{|c|}{ Field strain } \\
\hline & & P.f. & & P.f. & & P.f. & & P.f. \\
\hline Cyhalothrin & 0.013 & & 0.019 & & 0.011 & & 0.016 & \\
\hline Folic oil+Cyhalothrin & 0.004 & 3.25 & 0.007 & 2.71 & 0.002 & 5.50 & 0.005 & 3.20 \\
\hline Kemesol oil+Cyhalothrin & 0.006 & 2.16 & 0.009 & 2.11 & 0.003 & 3.66 & 0.007 & 2.28 \\
\hline National oil+Cyhalothrin & 0.012 & 1.08 & 0.015 & 1.26 & 0.010 & 1.10 & 0.013 & 1.23 \\
\hline
\end{tabular}

Potentietion factor (P.f.) $=\mathrm{LC}_{50}$ insecticide alone/ $\mathrm{LC}_{50}$ insecticide+Mineral oil. 
Table 3. In vivo inhibition of Spodoptera larvae $4^{\text {th }}$ instar ATPase activity by some compounds $\left(\mathbf{L C}_{50}\right)$

\begin{tabular}{lcc}
\hline Compounds & & \% Inhibition \\
\cline { 2 - 3 } & Lab strain & Field strain \\
\hline Cyhalothrin & 75.7 & 70.1 \\
Folic oil & 67.5 & 64.8 \\
Kemesol oil & 58.6 & 55.9 \\
National oil & 53.4 & 50.2 \\
\hline Folic oil+ Cyhalothrin & 95.8 & 90.7 \\
Kemesol oil+ Cyhalothrin & 90.5 & 88.6 \\
National oil+ Cyhalothrin & 76.2 & 71.3 \\
\hline
\end{tabular}

inhibition increased to be 76.2 and $71.3 \%$ for lab and

field strains respectively, when National oil pretreated with Cyhalothrin. Generally, the results proved that mixing of Folic and Kemesol oil with Cyhalothrin significantly induce increase in the inhibition percentages, but National oil had weak inhibitory effect on the ATPase. This results fully agree with Kaygisiz (1980) \& McDonald (1981) reported that synthetic Pyrethroids were the most effective against $4^{\text {th }}$ instar larvae of S. littoralis. Saleh et al., (1984) \& Korkor et al., (1995) reported that synthetic Pyrethroids were the most effective insecticides against Bollworm.

The potentiation of insecticides as a result of some tested Mineral oils may be attributred to affinity of some of their components and/or their fast reaction with detoxifying enzyme, forming a relatively stable substrate enzyme complex that block the detoxifying enzyme.

The in vitro inhibition of brain $S$. littoralis ATPase activity:

Table (4) show the in vitro interaction of Cyhalothrin and the three Mineral oils on ATPase activity of $S$. littoralis $4^{\text {th }}$ instar brain. The $\mathrm{I}_{50}$ values of Cyhalothrin for lab and field strains larval brain ATPase are 0.64 and $0.76 \mathrm{ppm}$ respectively. We have shown that the efficacy of Folic oil and Kemesol oil has a very good additive toxicity for Cyhalothrin in lab and field Spodoptera strains Table (4), because for the enhancement toxicity of the Folic oil and Kemesol oil, we study the in vitro biochemical interaction of them with the ATPase activity and compare with the Cyhalothrin in vitro effects. The $\mathrm{I}_{50}$ values for Folic oil 4.4 and 5.6ppm against both lab and field strains enzyme respectively, while when Folic oil mixed with
Cyhalothrin the $\mathrm{I}_{50}$ values were 0.28 and $0.47 \mathrm{ppm}$ for lab and field strains respectively. On the other hand the $\mathrm{I}_{50}$ values for Kemesol oil were 6.2 and 7.4ppm against lab and field strains enzyme respectively, the $\mathrm{I}_{50}$ values were 0.45 and $0.61 \mathrm{ppm}$ for lab and field strains respectively, when Kemesol oil mixed with Cyhalothrin. It is quite clear that Cyhalothrin at $\mathrm{I}_{50}$ concentration acts as potential inhibitor for Spodoptera larvae ATPase activity. These results are in agreement with many investigators. Desaiah et al., (1975); Saleh et al., (1984), and Korkor et al., (1995) reported that synthetic Pyrethroids were the most effective insecticides against ATPase of different insects.

To characterize more details about the in vitro inhibition of ATPase by the inhibitor, the $\mathrm{I}_{50}$ and $\mathrm{Ki}$ values of each inhibitor were estimated from the graphical method of Dixon and Weep, (1964) Table (4). The obtained data proved that compounds competitive inhibition of ATPase activity and the Ki values were 38 and $45 \mathrm{ppm}$ for Cyhalothrin alone, lab and field strains respectively. Ki values were 57 and 20ppm for Folic oil alone and mixed with Cyhalothrin for lab strain respectively, while, Kemesol oil exhibited competitive inhibition of activity as Ki values were 64 and 28ppm for Kemesol oil alone and mixed with Cyhalothrin for lab strain respectively. In the case of field strain the $\mathrm{Ki}$ values were 66 and 26ppm for Folic oil alone and mixed with Cyhalothrin respectively. Ki values were 72 and $34 \mathrm{ppm}$ for Kemesol oil alone and mixed with Cyhalothrin for field strain respectively. These results are in accordance with Hazzard et al., (2003) found that the combination of Bacillus thuringiensis and Mineral oil provided the largest and most consistent reduction in numbers of larvae.

Table 4. In vitro inhibition of brain Spodoptera larvae ATPase activity by certain compounds

\begin{tabular}{lcccc}
\hline \multirow{2}{*}{ Compounds } & \multicolumn{2}{c}{$\mathbf{I}_{\mathbf{5 0}}(\mathbf{p p m})$} & \multicolumn{2}{c}{ Ki $(\mathbf{p p m})$} \\
\cline { 2 - 5 } & Lab strain & Field strain & Lab strain & Field strain \\
\hline Cyhalothrin & 0.64 & 0.76 & 38 & 45 \\
Folic oil & 4.4 & 5.6 & 57 & 66 \\
Kemesol oil & 6.2 & 7.4 & 64 & 72 \\
\hline Folic oil+Cyhalothrin & 0.28 & 0.47 & 20 & 26 \\
Kemesol oil+Cyhalothrin & 0.45 & 0.61 & 28 & 34 \\
\hline
\end{tabular}


Generally, it could be concluded that use of Pyrethroids and mixtures with Mineral oils instead of conventional hazardous insecticides; were efficient as inhibitors for ATPase and this may reduce the environmental pollution and hazard effects on human health our data supported that, Mineral oils may play an important role in future insect pest management programs especially when mixed with Pyrethroids.

\section{REFERENCES}

Abbott, W. S. (1925). A method for computing the effectiveness of an insecticide. J. Econ. Entomol., 18: 265-267.

Abo-Shanab, A. L. (2005). Efficacy of somew IGRs/insecticide, $\mathrm{Kz}$ oil and binary mixtures on mortality and enzyme activity of Egyptian mealybug Iceria aegyptiaca (Douglas) attacked Guava trees Alexandria Governorate. J. Pest. Cont. and Environ. Sci. 13: 73-85.

Amer, S. A. A.; S. A. Saber, and F. M. Momen (2001). A comparative study of the effect of some mineral and plant oils on the two spotted spider mite Tetranychus urticae Koch (Acari: Tetranychidae). Acta. Phytopathologica et Entomolgica, Hungarica. 36: 165-171.

Chapman, P. J.; L. A. Riehl, and G. W. Pearce (1952). Oils sprays for fruit trees in: Insects; "The Year book of Agriculture" Ed., A. Steffetud, U.S.A. Washington, D. C. pp. 780 .

Desaiah, D.; Cutkomp, L. K.; Vea, E. V., and Koch, R. B. (1975). The effect of three pyrethroids on ATPases of insects and fish. Sci. J. Ser. 6: 31-34.

Dixon, M., and E. C. Weeb (1964). Enzymes. Academic press. Inc., New York. $2^{\text {nd }}$ Edition. 328-330.

El-Halawany, M. E.; A. M. Metwally, and M. E. Nassar (1987). Activity of albulium on the citrus brown mite biology and the sensitivity of different mite species to certain chemicals. Agric. Res. Rev. 65: 37-42.

El-Attal, Z. M.; O. K. Moustafa, and M. E. Keddis (1983). The ovicidal effect of local spray oils against the red mite and cotton leafworm. Proc. $5^{\text {th }}$ Arab Pesticide Conf., Tanta Univ., Sept., 2: 222-224.

El-Aw, M. A.; M. A. Marzouk, and M. Hashem (2002). Determination and biochemical characterization of resistance in field strains of the cotton leafworm. Spodoptera littoralis (Boisd.) (Lepidoptera: Noctuidae). J. .Pest. Cont. and Environ. Sci. 10: 37-54.

El-Sebae, A. H.; F. A. Hossam El-Deen; M. Abo El-Amayem, and A. El-Marei, A. (1976). Studies on the chemical structure and insecticidal activity of local spray oils. $2^{\text {nd }}$ Arab Conf.. Petrochem., Abo Dhabi 5: 4.

El-Deeb, M. F.; A. S. H. Abo-Shanab; Sahar, M. Beshr, and K. S. Moursi (2002). Different types of pesticides and their mixtures for controlling the olive tree scale insect Leucaspis racae Targ. On olive trees fogging and spraying machine a machine at Burg El-Arab area. $2^{\text {nd }}$
International Conference, plant Protection Research Institute, Cairo, Egypt, 21-24 December, 2002: 882-885.

Finney, D. J. (1971). Probit analysis, $3^{\text {rd }}$ ed Cambridge Univ. Press, Cambridge, England.

Hazzard, R. V.; B. B. Schultz; E. Groden; E. D. Ngollo, and E. Seidlecki (2003). Evaluation of oils and microbial pathogens for control of Lepidopteran pests of sweet corn in new England. J. Econ. Entomol., 96: 1653-1661.

Hopkins, A. R.; R. F. Moore, and W. James (1982). Efficacy of diflubenzuron diluted in three volumes of oils on Bollweevil progeny. J. Econ. Entomol. 75: 385-386.

Ishaaya, I., and M. Klein (1990). Response of susceptible laboratory and resistant field strains of Spodoptera littoralis (Lepi.: Noct.) to teflubenzuron. J. Econ. Entomol., 83: 59-62.

Ismail, A. A.; Wafaa, H. Hegazi; A. S. Derbalah; Nahed, E. Hasan, and S. A. Hamed (2006). Toxicological and biological studies of some compounds against the two spotted spider mite, Teranychus urticae and its predatory mite, Amblyseius gossipi on different host plants. J. Pest. Cont. and Environ. Sci., 14: 227-256.

Kaygisiz, H. (1980). The biological efficiencies of the synthetic pyrethroids on Egyptian cotton leafworm $S$. littoralis (Boisd.). Turkeye Bitki Koruma Dergisis. $o$ : 171-174.

Keddis, M. E.; F. A. Ayad; M. S. Abdel-Fattah, and M. A. ElGuindy (1988).Studies of resistance to urea derivatives and their mixtures with insecticides in field strains of cotton leafworm, Spodoptera littoralis (Boisd.) during the cotton seasons 1983, 1984 and 1985. Bull. Ent. Soc. Egypt, Econ. Ser. 15: 229-234.

Koch, R. B.; L. K. Cutkomp, and F. M. Do. (1969). Chloinated hydrocarbon insecticide inhibition of cockroach and hony bee ATPase. Life Sci. 8: 289-297

Korkor, A. A.; M. Z. F. Awad; A. M. Hamid, and M. B. AboSalem (1995).

Screening of some insecticides against Bollworm and whitefly attacking cotton plants. Com. In Sci. and Dev. Res. 50: 141-157.

Lowery, O. H.; N. J. Rosebrough; A. L. Farry, and R. J. Randall (1951). Protein measurements with folin phenol reagent. J. Bio. Chem. 193: 265-271.

MARL (1997). "Agricultural pest control program" Annual book of Ministry of Agriculture and Land Reclamation, Egypt, pp. 5-40.

Martin, T.; G. O. Ochou; F. Hala-Nklo; J. M. Vassal, and M. Vayssaire (2000). Pyrethroid resistance in the cotton Bollworm, Helicoverpa armigera, in West Africa. Pest. Manag. Sci., 56: 549-554.

McDonald, S. (1981). Evaluationof organophosphorus and pyrethroid insecticides for control of pale Western Gutworm. J. Econ. Entomol. 74: 47-48

Micks, D. W., and J. A. Berlin (1970). Continued susceptibility of Culex pipiens to petroleum hydrocarbons. J. Econ. Entomol 63: 1996. 
Mohmoud, M.; M. Soliman, and Ola, O. El-Fandary (2006). Field performances of certain mineral oils against fig scale insect, Russellaspis pustulans (Cockerell) (Homoptera: Asterolecaniidae) on apple trees in new reclaimed lands in Egypt. Bull. NRC, Egypt. 31: 147157.

Morshedy, M. (1980). Comparative study on enzymes and metabolic inhibitors. Ph. D. Thesis, Alexandria University. Pp. 157.

Moustafa, O. K., and Z. M. El-Attal (1985). Enhancement of the efficiency of some was found insecticides against thrips and cotton leafworm by mineral oils. J. Agric. Sci.. Camb. 105: 63-66.

Moursi, K. S. (1996). Integrated Pest Management of Olive, Almond, Fig and Guava in Northern Western Coast of
Egypt. Roport $4^{\text {th }}$ (Project No. 6 funded by Regional Council for Agricultural research and Extension). P 80.

Omar, H. I. H.; M. F. Hayder, and Y. H. Issa (1987). Effect of some oil- insecticide mixtures on aphids and thrips infesting tomato. Agric. Res. Rrv. 47: 47-52.

Rodriguez, J. G.; J. M. Campbell, and K. G. Eveleens (1966). Effect of some oil-insecticide combinations on coffee leaf miner. J. Econ. Entomol 59: 773-779.

Saleh, R. S.; M. Morshedy, and M. El-Gamal (1984). Effect of some plant volatile oils on the in vitro activity of ATPase from torpedo fish electric organ and rat brain and heart. J. Agric. Res. Tanta Univ. 10: 678-685.

Taussky, H. H., and E. Shorr (1953). A microlorimetric method for the determination of inorganic phosphorus, J. Bio. Chem. 202: 675-685. 


\title{
الملخص العربي
}

\section{كفاءة بعض الزيوت المعدنية ومبيدات البيرثرويد ومخاليطهم على نشاط أنزيم أدينوسين تراى فوسفاتيز خارجياً فى يرقات دودة ورق القطن}

\author{
سهام منصور إسماعيل، نادر شاكر
}

للتثبيط هي 90.5\% 88.6 \% م لكل من السـلالة المعملية والحقلية

على التوالى، ولقد كانت النسبة المئوية للتثبيط بواسطة الناشيونال بعد

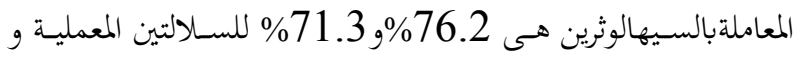
الحقلية على الترتيب. وكذلك تم دراسة تأثير تلك الزيوت المختبرة بعد المدار

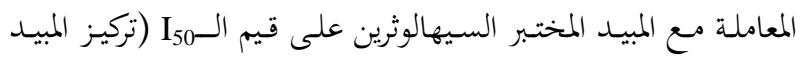
اللازم لتبيط50\% من النشاط الأنيمى).وأيضا دراسة ثابت التثبيط ولقد أثنتت النتائج حدوث أنخفاض فن تلك القيم وكانت أعلى لـ

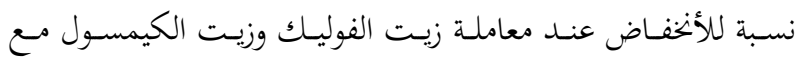

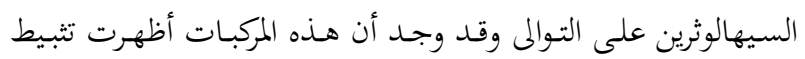

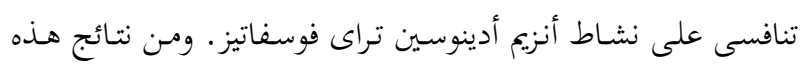

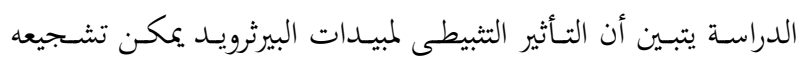

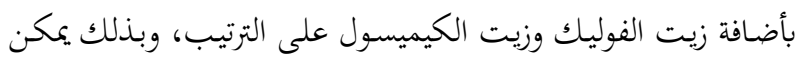

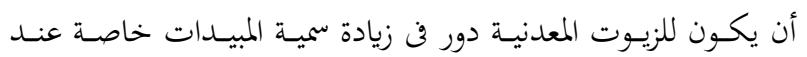

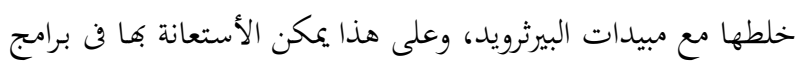
المكافحة.
تم دراسـة سميسة ثلاثـة مـن الزيـوت المعدنيـة وهـى (فوليـك-

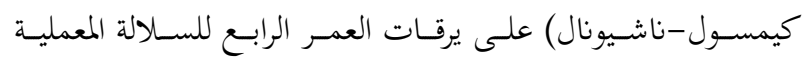

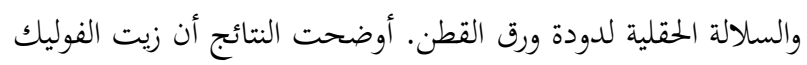

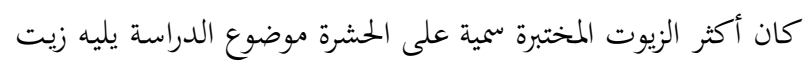

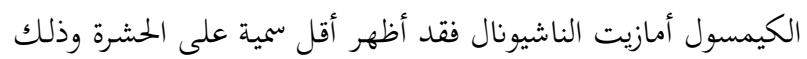

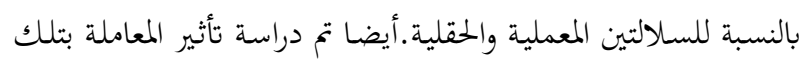

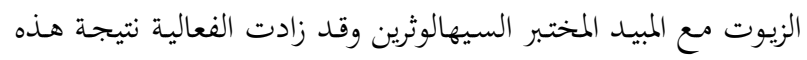

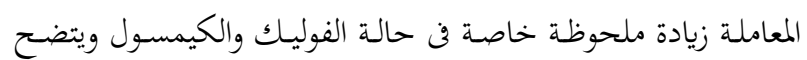

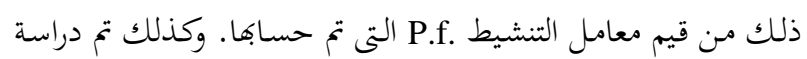
المقـدرة التثبيطيـة للزيوت المختـبرة على النشـاط الأنيمسى لأنزيم هـام

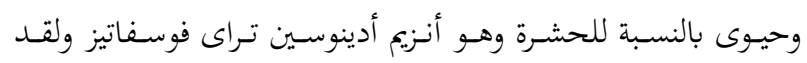

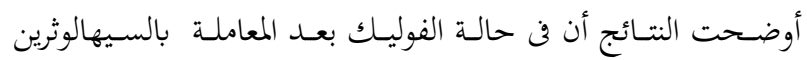

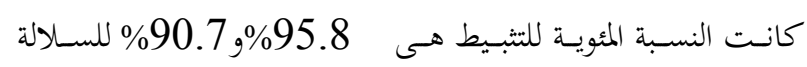

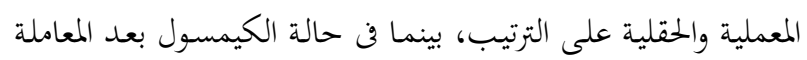
بالسيهالوثرين كانت النسبة المئوية 